\title{
After 12 years Profa. Regina Celia Nunes departs as Associated Editor of Polímeros
}

\author{
Sebastião V. Canevarolo ${ }^{1}$ \\ ${ }^{1}$ Editor-in-Chief, Polímeros, Departamento de Engenharia de Materiais - DEMa, Universidade Federal de \\ São Carlos - UFSCar, São Carlos, SP, Brasil
}

As already mentioned in past editorials, from now onwards all articles of Polímeros will be published in English. With this major step forward Polímeros can be available to the broadest scientific community, from any part of the world, just enough to have an internet connection nearby. Now we can say that its original objectives, to spread the latest achievements of the polymer researchers, is been fully attained.

In the last few years Polímeros is steadily getting greater recognition by the researchers working in the polymer area. This has led to a great increase in the influx of submitted articles, and more important of all, having better fundamental scientific importance. The consequence was the increase of the number of accepted article to be published. In its last meeting the Council Board of Polímeros has decided to increase the number of articles to be published to 60 per year, keeping the number of articles per issue constant of 12 . Then the number of issues has been raised to five per year, with the following periodicity: $1^{\circ}$ Issue (Jan, Feb, Mar), $2^{\circ}$ Issue (Apr, May), $3^{\circ}$ Issue (Jun, Jul), $4^{\circ}$ Issue (Aug, Set) e $5^{\circ}$ Issue (Oct, Nov, Dec).

After serving as Associated Editor of Polímeros for 12 years Profa. Regina Celia Reis Nunes of Universidade Federal do Rio de Janeiro-UFRJ has retired. We acknowledge her great job, responsible for the articles dealing with vulcanized natural and synthetic rubbers and elastomers, publishing many articles in Polímeros, the most recent ones ${ }^{[1-4]}$. She will remain as member of the Editorial Board, helping us with her deep knowledge stored from many decades of working experience. Thank you Profa. Regina, the whole community is indebted to you.

\section{References}

1. Silva, V. M., Nunes, R. C. R., \& Sousa, A. M. F. (2017). Epoxidized natural rubber and hydrotalcite compounds: rheological and thermal characterization. Polimeros: Ciência e Tecnologia, 27(3), 208-212. http://dx.doi.org/10.1590/0104-1428.03416.

2. Honorato, L., Dias, M. L., Azuma, C., \& Nunes, R. C. R. (2016). Rheological properties and curing features of natural rubber compositions filled with fluoromica ME 100. Polimeros: Ciência e Tecnologia, 26(3), 249-253. http://dx.doi.org/10.1590/01041428.2352.

3. Bezerra, F. O., Nunes, R. C. R., Gomes, A. S., Oliveira, M. G., \& Ito, E. N. (2013). Efeito Payne em nanocompósitos de NBR com montmorilonita organofílica. Polimeros: Ciência e Tecnologia, 23(2), 223-228. http://dx.doi.org/10.1590/S0104-14282013005000022.

4. Mariano, R. M., Nunes, R. C. R., Visconte, L. L. Y., \& Altstaedt, V. (2013). Effect of montmorillonite and cellulose ii hybridization on mechanical properties of natural rubber nanocomposites. Polímeros: Ciência e Tecnologia, 23(1), 123-127. http://dx.doi. org/10.1590/S0104-14282013005000012.

\section{Short CV of Profa. Dra. Regina Celia Reis Nunes}

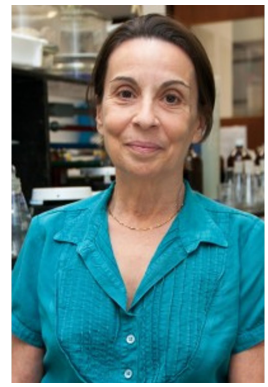

She holds a Licentiate degree in Chemistry from Universidade Estadual do Rio de Janeiro (1968), a Master's degree in Organic Chemistry from the Instituto de Química of the Universidade Federal do Rio de Janeiro, UFRJ (1975), a PhD in Polymer Science and Technology from the Instituto de Macromoléculas of the UFRJ (1989) and Post-Doctorate by the Consejo Superior de Investigaciones Científicas, Madrid, Spain (1994). She is Adjunct Professor 4 at UFRJ since 1990 and is currently a Guest Professor at the Instituto de Macromoléculas Professor Eloísa Mano of the UFRJ. She is an expert in Rubbers and Elastomers, working mainly on the following topics: Polymer/cellulose nanocomposites, Elastomeric composites with special properties, and Mineral loading in polymer compositions. She was a member of the Editorial Board of Polímeros as Associated Editor since 2006. 